\title{
Evaluation of Openers for Seeding Meadow Brome Grass (Bromus riparius) Using Air Delivery Seeding Systems
}

\author{
Duane McCartney, ${ }^{1}$ Gord Hultgreen, ${ }^{2}$ Allan Boyden, ${ }^{2 *}$ \\ and Craig Stevenson 3
}

\author{
Authors are ${ }^{1}$ Pasture Management Research Scientist, Agriculture \& Agri-Food Canada, 6000 C \& E Trail, Lacombe, \\ AB T4L 1W1, Canada; ${ }^{2}$ Agronomists, Prairie Agricultural Machinery Institute, Box 1150, Humboldt, SK SOK 2A0, Canada; \\ and ${ }^{3}$ Research Scientist, 142 Rogers Road, Saskatoon, SK S7N 3T6, Canada.
}

\begin{abstract}
There is interest in Canada in seeding grass seed using air seeders and air drills that were originally designed for seeding cereals and oilseeds. These seeders use an air delivery system to move the seed from large grain tanks on the seeder to the cultivator furrow openers for seed placement in the ground. Various types of furrow openers (i.e. spoons or knives) were evaluated for their effectiveness in placing meadow brome grass seed (Bromus riparius [Rehmann]) in the ground. Knife openers provided the best seed emergence results. Seed brakes and variable air velocities were also evaluated as a means of preventing the seed from blowing out of the seed row when using high air velocities. The screen-type seed brakes were prone to plugging with the grass seed. Acceptable seeding results were achieved without seed brakes when used at low air velocities; however, at these lower air velocities, seed distribution may be less accurate. It was also shown that when monoammonium phosphate (11-51-0) was mixed with the meadow brome grass seed at $33 \mathrm{~kg} \cdot \mathrm{ha}^{-1}$ as a means of preventing seed bridging in the delivery system, the seedling emergence counts were significantly less than applying the fertilizer at the point where the seed enters the openers.
\end{abstract}

\section{Resumen}

En Canadá hay interés en sembrar zacates usando sembradoras de aire y sembradoras en hileras de aire, las cuales originalmente fueron diseñados para sembrar cereales y oleaginosas. Estas sembradoras usan un sistema de aire para mover la semilla de grandes tanques de granos localizados en la sembradora a los surcadores para colocar la semilla en el suelo. Se evaluaron varios diseños de abridores de surcos (por ejemplo, cucharas o cuchillos) para determinar su efectividad en colocar la semilla "meadow brome grass" (Bromus riparius [Rehmann]) en el suelo. Los abridores de cuchillo dieron los mejores resultados de emergencia. También se evaluaron frenos de semilla y velocidades de aire variables como medios de prevenir que la semilla se vuele fuera del surco cuando se usan velocidades altas de aire. Los frenos de semilla del tipo de malla fueron susceptibles a taparse con la semilla de zacate. Se lograron resultados aceptables de siembra sin los frenos de semilla cuando se utilizaron a velocidades bajas de aire; sin embargo, a estas velocidades bajas de aire la distribución de la semilla puede ser menos certera. También se demostró que cuando se mezcló fosfato monoamonio (11-51-0) en dosis de $33 \mathrm{~kg} \cdot \mathrm{ha}^{-1}$ con la semilla de "meadow brome grass" como medio de prevenir que la semilla se atore en el sistema de despacho, los conteos de emergencia de la semilla fueron significativamente menores que aplicando el fertilizante en el punto donde la semilla entra en los abridores.

Key Words: forage seeding, air seeder, openers

\section{INTRODUCTION}

Conservation tillage is being adapted in most regions of the Canadian prairies because of the benefits of reduced erosion and improved soil moisture conservation for germination, the reduction in nonselective herbicide costs, and the development of high-clearance air seeding equipment (Johnston et al. 2003). Air seeders and air drills developed and manufactured in the Northern Great Plains deliver seed through an airway delivery system from a large grain tank on the seeder to cultivator shank furrow openers. The units can be up to $18 \mathrm{~m}$ in width, thus

*Deceased.

Correspondence: Dr Duane McCartney, Agriculture \& Agri-Food Canada, 6000 C \& E Trail, Lacombe, AB T4L 1W1, Canada. Email: McCartneyD@agr.gc.ca

Manuscript received 21 May 2003; manuscript accepted 11 November 2004. allowing for large areas to be seeded in a short time. Air seeders have all the weight of the cultivator on support wheels and no weight on the packer wheels, whereas the air drill cultivator attachment has the weight distributed to caster wheels on the front and the packer wheels on the back. Over the years, only the cultivator attachment has changed design, and the seed tanks and air delivery systems have remained the same. In previous work by McCartney et al. (1997, 2005), agitation systems were developed for seeding forage grasses using the different air seeders manufactured in the Northern Great Plains. Further development and testing was required to develop air velocity or fan speed parameters and to test the effectiveness of various types of soil openers and seed brakes for maintaining accurate grass seed placement. Seed brakes are devices that fit between the air delivery hoses and the seed openers to reduce the velocity of seed and prevent seed bounce or blowout. The object of this study was to evaluate the 


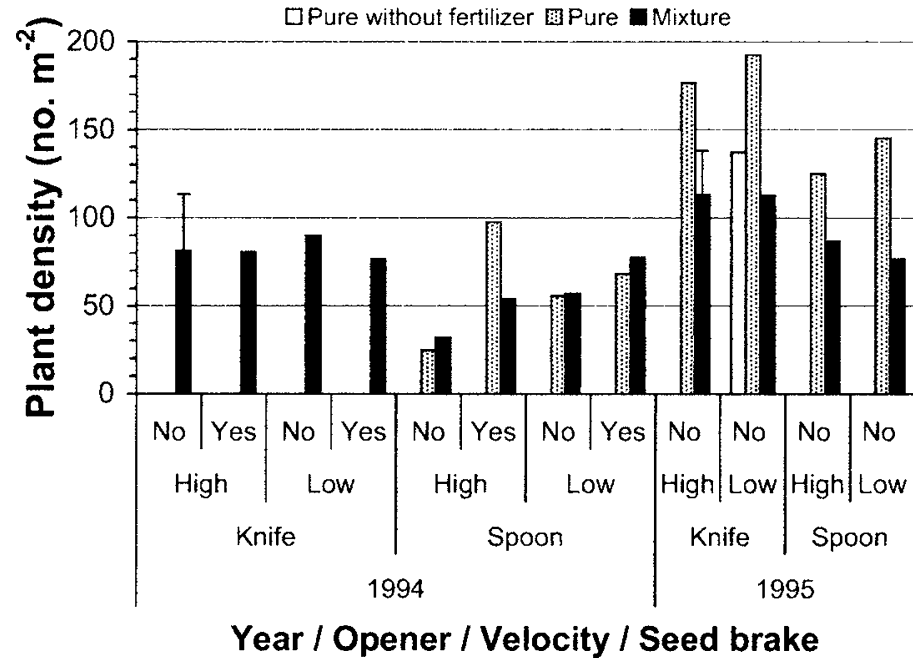

Figure 1. Mean meadow brome plant emergence for combinations of opener type and seed brake or opener type, high and low air velocities, pure seed or a mixture (seed plus fertilizer), for the Valmar 4400 plot seeder. Error bars with means represent $L_{S D_{0.05}}$ to compare stand for different treatment levels.

effectiveness of using an air seeder to seed grass seed using knife- and spoon-type soil openers and seed brakes under different airflow rates. A second objective was to evaluate seed emergence when fertilizer is mixed with the seed as a means of preventing bridging in the seed delivery system.

\section{MATERIALS AND METHODS}

Field experiments were conducted for 2 consecutive years (1994-1995) by Prairie Agricultural Machinery Institute (PAMI) near Humboldt, Saskatchewan, Canada. (McCartney et al. 1997; PAMI 1997). Test plots $(3 \times 9 \mathrm{~m})$ were established over the 2 years to compare types of seeding openers, knife vs. spoon, and the use of seed brakes, with high and low airflows when seeding pure meadow brome grass (Bromus riparius [Rehmann]) or in a seed and fertilizer mixture.

The treatments were all seeded with 11-51-0 (monoammonium phosphate) fertilizer mixed with the seed or metered from the fertilizer box and applied separately at the point where the seed enters the openers. The application rates in year 1 was 11 $\mathrm{kg} \cdot \mathrm{ha}^{-1}$ of meadow brome grass seed and $28 \mathrm{~kg} \cdot \mathrm{ha}^{-1}$ of fertilizer and $13 \mathrm{~kg} \cdot \mathrm{ha}^{-1}$ of meadow brome grass seed and 33 $\mathrm{kg} \cdot \mathrm{ha}^{-1}$ of fertilizer in the second year. An additional treatment in the second year consisted of seeding meadow brome seed without fertilizer to serve as a check to ensure that seedling emergence was not reduced by mixing the seed with the fertilizer, as is normally done to prevent pure seed bridging or blockage in the seed delivery system. At the start of seeding each treatment, the flow from each metering cup was checked to ensure that seed and fertilizer were flowing to each opener. The settings used were always made by one person and checked by another. All plots were direct seeded into standing stubble with the PAMI plot air seeder. The plot air seeder was $3 \mathrm{~m}$ wide and based on a 5 -rank cultivator with $20-\mathrm{cm}$ row spacing. The seed and fertilizer was gravity fed into a Valmar 4400 air delivery system. This pneumatic system was designed for

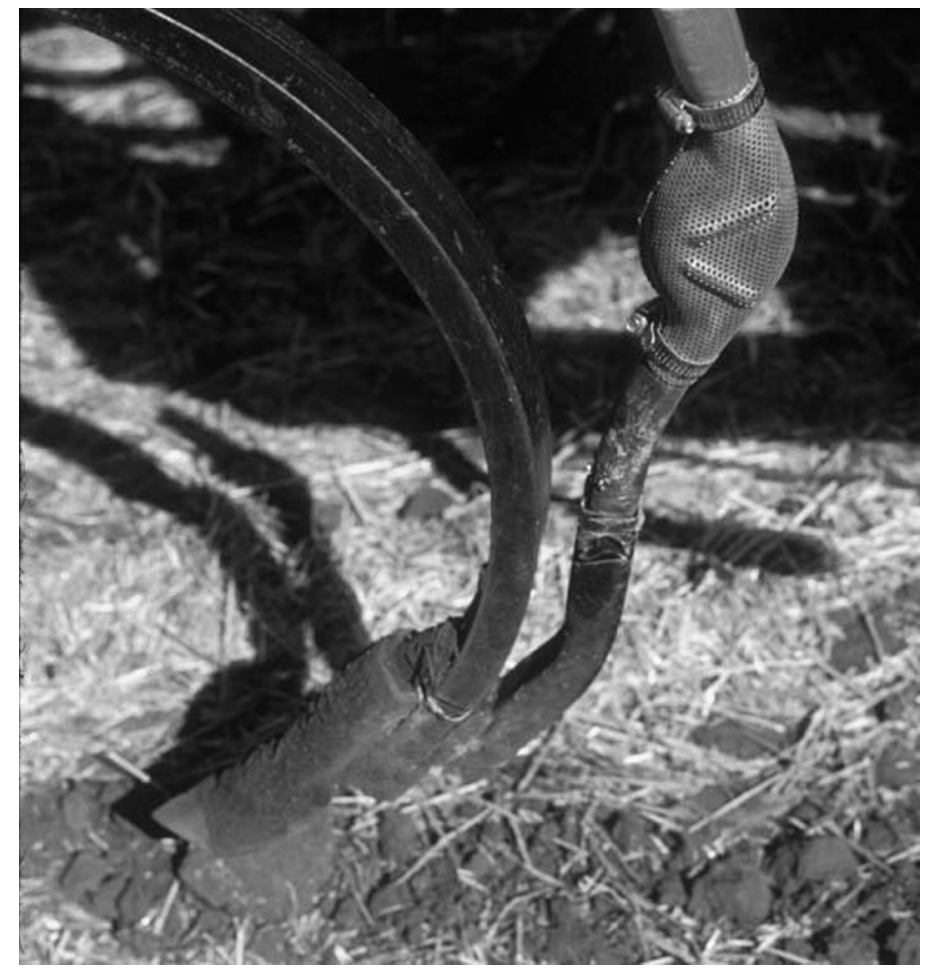

Figure 2. Seed air brake for air delivery system seeder.

various combinations of seed and fertilizer. Seed row packing was provided by rear-mounted plastic gang packers. The plots were seeded during the first week of June each year in a randomized complete block design with 4 replicates. Seed emergence counts were taken at 2 different locations on each replicate 2 weeks after seeding each year.

Plant density data were analyzed separately with the PROC MIXED procedure of SAS (Littel et al. 1996). A randomized complete block design was used to analyze the effect of opener configurations. Similar and different variance estimates for different treatment combinations were parameterized for the analysis of each experiment. The log-likelihood parameter estimates for the analysis of a given experiment were compared with a restricted likelihood ratio test having a chi-square distribution to determine if variances were similar among the treatment combinations. Treatment effects and variance component comparisons were declared significant at $P<0.05$.

\section{RESULTS AND DISCUSSION}

In year 1 for unknown reasons, the last 4 treatments using the knife had more than double the emergence of most other plots (Fig. 1). These treatments were not seeded consecutively; however, all 4 were seeded near the end of the day. The dramatic difference in emergence suggests it is possible that an error occurred in adjusting the seeding rate in year 1 , and these data were not included in the analysis. Although the emergence counts were inconclusive in year 1 , several observations could be made. Spoon openers with no seed brakes and high air velocity resulted in lower plant densities in year 1 . The air brakes (Fig. 2) that were used during the test consisted of a screened body to vent high volumes of air and a baffle plate to restrict airflow to 
the seed tube of the opener. The screens of the air brakes began to plug with the meadow brome grass seed, and it is highly likely that the seed brakes used would eventually plug completely. The use of seed brakes of this type is consequently not recommended for seeding grass seeds. High and low airflows did not greatly affect seed emergence. Significant differences in emergence occurred for the 9 treatments conducted in the second year (Fig. 1). The plots seeded with the seed and fertilizer mix together had significantly less emergence than the plots seeded with the seed and fertilizer separated. Meadow brome grass seed was mixed with the fertilizer the day before the plots were seeded. The germination of the seed could have been reduced by mechanical damage to the meadow brome seed during the manual mixing process. Thus, mixing fertilizer with the grass seed as a means of preventing seed blockage or bridging in the seed delivery system reduced germination emergence.

The knife openers provided better emergence than the spoon openers $(P<0.05)$. This may have been caused by better seed placement into a narrow row where the packing and moisture were more effective. These findings were similar to Tessier et al. (1991) where they found that hoe openers increased soil disturbance, slightly reduced bulk density in the seed furrow, improved soil-water availability, but reduced the rate of spring wheat seedling emergence by 8 plants $\cdot \mathrm{m}^{-2} \cdot \mathrm{d}^{-1}$. The graph of the data suggests that there is reduction in emergence with greater airflow when comparing the pure seed treatments with the knife and spoon openers. However, this difference was not statistically significant in the context of experimental precision achieved in this study.

The fertilizer check treatment in the second year had less emerged plants than the pure brome grass seed treatment with the same opener and air velocity configuration $(P<0.05)$ but similar levels of plant density when the brome grass plus 11-51-0 mixture was seeded (Fig. 1). It appeared that the phytotoxic damage, if any, from 11-51-0 is clearly offset by the benefit of the fertilizer for seedling vigor. It confirms that seed row-placed fertilizer (11-51-0) did not detrimentally affect plant emergence. The data also suggests that airflows should be kept lower when seeding pure seed. All manufacturers provide minimum fan speed settings for their air seeders. The lowest possible settings should be used to ensure good seed placement and uniform distribution of the seed through the air delivery system.

In western Canada, current cropping trends are indicating increased popularity of seeding grass seed and other forages. Concurrent with these cropping trends has been a shift from press drill and air seeders to air drills, an air seeding implement with about $50 \%$ of the implement weight shifted from the frame wheels to the packer wheels (PAMI, personal communication). There are a couple of points to consider with regard to the optimal establishment of bromegrass and other forages with current air seeding implements. Seeding forages into lighter/drier soils may benefit from the heavier packing pressure of the air drill vs. air seeder by increasing seed:soil moisture contact, consequently increasing the chance of obtaining uniform germi- nation and establishment. However, this additional packing pressure with air drills may result in overpacking and soil crusting that will impede the emergence/establishment when seeding into heavy-textured or moist soils. In hilly land, the ground-following action of an air seeder with a floating hitch could result in better seeding accuracy than with the groundfollowing action of an air drill because of the shorter distance between the in frame wheels and the caster wheels on the air seeder compared to the larger distance between the packer and caster wheels on an air drill. Future forage research might consider the implications of seeding forages into different seed bed conditions and possible interactions with opener types.

\section{SUMMARY}

In this study, knife openers provided the best emergence results for seeding meadow brome grass. Seed brakes were used to prevent the seed blowing out of the seed row with high air velocities, but it appeared that the screens on the seed brake units used will plug. This may pose a problem, at least with the style of seed brake used in the test. Without seed brakes, airflows should generally be set to the lowest flow rate that prevents plugging. When meadow brome grass was mixed with monoammonium phosphate (11-51-0) as a means of preventing seed bridging in the air delivery system, there were significantly less seedling emergence counts than plots seeded with the seed and fertilizer separated until the point of entry at the seed openers.

\section{ACKNOWLEDGMENTS}

The authors would like to thank the Canada Green Plan and Ducks Unlimited for their financial support.

\section{LITERATURE CITED}

Johnston, A., G. Lafond, W. May, G. Hnatowich, and G. Hultgreen. 2003. Opener, packer wheel and packing force effects on crop emergence and yield of direct seeded wheat, canola and field peas. Canadian Journal of Plant Science 83:129-139.

Littel, R. C., G. A. Milliken, W. W. Stroup, and R. D. Wolfinger. 1996. SAS System for Mixed Models. SAS Institute, Cary, NC. p 656.

McCartney, D., A. Boyden, G. Hultgreen, P. Leduc, and J. Wassermann. 1997. Improving the air seeding of meadow brome grass. Prairie Agricultural Machinery Institute, Humboldt, SK. Final Report RH0793. p 37.

McCartney, D., G. Hultgreen, A. Boyden, and C. Stevenson. 2005. Development of agitators for seeding forages using air delivery systems. Rangeland Ecology \& Management. 58:199-203.

[PAMI] Prarie Agricultural Machinery Institute. 1997. Air seeding forage crops. PAMI, Humboldt, SK. Research Update 733. p 4.

Tessier, S., K. Saxton, R. Papendick, and G. Hyde. 1991. Zero-tillage furrow opener effects on seed environment and wheat emergence. Soil Tillage Research 21:347-360. 